\title{
Which pathway to address interrelated challenges to farm sustainability in Thailand? Views of local actors
}

\author{
Nicolas Faysse ${ }^{1,2}$ (C) $\cdot$ Kassirin Phiboon ${ }^{3} \cdot$ Man Purotaganon $^{4}$ \\ Received: 9 April 2021 / Accepted: 18 December 2021 / Published online: 14 January 2022 \\ (c) The Author(s), under exclusive licence to Springer-Verlag GmbH Germany, part of Springer Nature 2022
}

\begin{abstract}
Farms in Asian newly industrialised economies are increasingly faced with operational and structural challenges (e.g. small farm size, ageing of farmers). Public policies have generally focused little on several of these structural challenges or on links between the challenges facing farms. The future of these farms looks uncertain. However, in Thailand, multi-stakeholder dialogue on this future has been limited. This article analyses possible farm futures that actors of a rural territory in Thailand identified and the changes they were willing to support to address interrelated challenges facing the farms. These farm futures resulted from a participatory planning process, which mostly involved farmers and staff from local administrations and public agencies. Participants designed future farm scenarios that took the main operational and structural challenges facing the farms into account. The pathway designed by participants to achieve their preferred scenario involved intervention of various dimensions, e.g. water management, value chains, and farm structure. Actors expressed their readiness for several farming system transformations. They proposed actions to enhance land tenure security and youth engagement in farming, which were two topics relatively overlooked in prevailing public policies. Supporting discussions between actors of rural territories could help identify ambitious innovative pathways to address challenges to farm sustainability in Asian newly industrialised economies.
\end{abstract}

Keywords Farm structure $\cdot$ Irrigated areas $\cdot$ Participatory scenario planning $\cdot$ Thailand $\cdot$ Transformative actions

\section{Introduction}

In Asian newly industrialised economies (NIEs), ${ }^{1}$ many farms are increasingly faced with structural challenges in addition to those related to their daily operations. A first structural challenge is the small farm size, which often

Communicated by: Chandni Singh

Nicolas Faysse

faysse@ cirad.fr

Kassirin Phiboon

kassirinp@gmail.com

Man Purotaganon

purotaganon@gmail.com

1 CIRAD, G-Eau Research Unit, Montpellier University, Montpellier, France

2 National Institute of Agronomy of Tunisia, 43 Avenue Charles Nicolle, 1082 Tunis, Tunisia

3 Sustainable Agriculture Foundation, Nonthaburi, Thailand

4 Thai Water Partnership, Bangkok, Thailand limits farmers' ability to make a living from farming (Rigg et al. 2016). In these countries, an increasing share of rural household income comes from non-farming activities, leading to a decrease in the importance paid to farming (Lorenzen 2015; Moya et al. 2015; Nathan and Rosli 2016; Ozturk 2009). A second structural challenge relates to the ageing rural population, accompanied by a decrease in the available work force (Bhandari and Mishra, 2018; Liao et al. 2019). This especially concerns the agricultural labour force $(\mathrm{Li}$ and Sicular 2013) since many youths refrain from engaging in farming (Moya et al. 2015; Ngah et al. 2013; Susilowati 2014). Structural challenges and operational challenges (e.g. concerning farming practices and management) are interrelated. Young people are often not interested in farming when the profit-making potential is limited, even when considering taking up farming as a secondary activity (Jansuwan and Zander 2021; Ruiz-Salvago et al. 2019).

The future of farms in Asian NIEs thus looks uncertain, especially since public policies over the past 20 years have

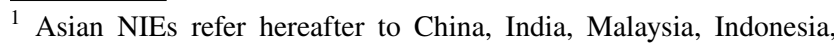
Thailand, Vietnam and the Philippines.
} 
generally focused on only a few of these challenges while paying limited attention to the relations between them (Hamilton-Hart 2019; Xue et al. 2020). These policies have generally concerned farm practices and management, with more structural issues (farm size, characteristics of the farming population, but also land tenure, etc.) taking a back seat (Huang 2019; Losch et al. 2016; Rigg et al. 2016). Policies to tackle the ageing farmer issue are incipient (Faysse et al. 2019). None of these policies have offered a pathway of change that considers these challenges overall so as to ensure farm sustainability in the future.

Studies have considered the future of agricultural production in Asian NIEs. Some focused on the impacts of climate change on agricultural production (e.g. Zhao and Wang 2020), while others analysed the future impacts of changing farming practices (e.g. Purushothaman et al., 2013; Sawaengsak et al. 2021) or the future impacts of policies on farmed areas (Ashok et al. 2021). Only a few studies have proposed scenarios regarding future changes in farm structures in Asian NIEs. They outlined various scenarios, e.g. stabilisation of smallholders' livelihoods based on both farming and non-farming activities, the replacement of smallholder farms by large-scale farms or farming companies, or de-intensification of farming practices (Lorenzen 2015; Rigg et al. 2016).

Involving actors of rural areas in thinking farm futures could be helpful in designing change scenarios based on concrete farm cases and challenges facing these farms. Such discussions at the local level can also show the extent to which these actors would be ready to build coalitions for change (Sartas et al. 2020). However, there have been few studies of rural actors' views on likely future changes of farming systems in Asian NIEs, or on the changes these actors would support. Hutton et al. (2021) asked local actors in Vietnam to judge the plausibility and desirability of various scenarios in terms of future farm structure and farming practices. The authors of some studies organised participatory scenario planning that considered the future of rural communities in Asian NIEs (Bennett et al. 2016; Bourgeois et al. 2017; Butler et al. 2016). These three studies also supported local actors in identifying a strategy or a pathway of change to achieve their preferred scenario. These pathways of change can combine incremental actions (i.e. actions aimed at improving the functioning of farming systems, generally to face operational challenges) and actions to transform farming systems (which may be necessary to address structural challenges, Hadarits et al. 2017).

However, studies reported constraints to actors' willingness to consider the main challenges facing farms when jointly designing a pathway of change in Asian NIEs. First, local actors may be willing to consider a wide range of challenges when designing scenarios, yet when building a strategy they may focus on incremental solutions offering less risky short-term gains (Butler et al. 2016). Second, actors may feel more at ease in considering drivers of change at the local level compared to those at a higher level (Bourgeois et al. 2017). Third, several studies showed that farmers in Asian NIEs often tailored their discourse and strategies visà-vis the state to their perception of the functioning of state administrations, of existing power asymmetries and of the type of support that these administrations were able to provide (Corbridge et al. 2005; Xiaoyun and Xiaoqian 2010).

This paper analyses possible farm futures that actors of a rural territory in Thailand identified and the changes they were willing to support to address interrelated challenges facing the farms. These farm futures and proposed changes emerged from a participatory scenario planning process. The latter draws on the results of a preliminary assessment phase that led to the identification of challenges facing farms in the study area (Faysse et al. 2020).

\section{Thai farms: many challenges, few explored futures}

Thailand is a key example of the above-mentioned agricultural and rural dynamics that prevail in Asian NIEs and of the influence of the past relations between the state and farmers in constraining discussions on the future of farms. In Thailand, according to the agricultural censuses, the average age of farm holders increased from 47 in 1993 to 53 in 2013. This was due to an increase in the number of elder farmers (related to ageing of the overall population) and to a marked decrease in the number of young people involved in agriculture (Rigg et al. 2020). It is hard to come up with a clear-cut definition of what it means to be a farmer in Thailand nowadays because of the high involvement of farming households in non-farming activities (Rigg et al. 2020). The findings of several studies conducted at a local scale (Formoso 2016; Nilsen 2014; Podhisita 2017; Rigg et al. 2012) complement the data provided by agricultural censuses and reveal that the farming population is ageing. The impact of this ageing trend on farm practices is a topical issue (Jansuwan and Zander 2021). In Thailand, a shift towards more extensive farming practices, a focus on production for home consumption and more limited adoption of agricultural innovations have been reported (Nilsen 2014; Rigg et al. 2020). Moreover, many ageing farmers rely on hired labour, leading to higher production costs (Formoso 2016). Farming has become a secondary activity for an increasing number of rural households. The decreasing economic and cultural role of farming in many rural communities could be qualified as a deagrarianisation process (Rigg et al. 2018).

Few planning initiatives have focused on the future of the Thai agricultural sector at local and national levels. A national strategy has been designed for the 2017-2036 
period (Office of Agricultural Economics 2017). This strategy is based on the "sufficiency economy philosophy", which has been a cornerstone of official political thinking on agriculture for decades in Thailand (Egery 2014). Broadly speaking, the sufficiency economy philosophy considers that small-scale farmers should produce multiple crops for both home consumption and the market, while using rational amounts of pesticides and chemical fertilisers (Tubtim 2019). The 2017-2036 national strategy acknowledges that Thai farms face several challenges, including low farm profitability and the ageing farming population. It sets ambitious objectives in terms of production. However, the strategy does not detail how the acknowledged challenges will be addressed or the objectives met. Planning at provincial, district and subdistrict levels is organised with little public participation, partially due to the lack of capacity of local administrations (Dufhues et al. 2015; Lorsuwannarat 2017).

The historical relationship between farmers and the Thai state has hindered opportunities for the participatory design of a pathway of change towards more sustainable farms. Since the 1990s, Thai agricultural policies have mainly aimed at maintaining existing farms, rather than transforming them and, importantly, raising their productivity (Walker 2015). This has been the case with regard to the most costly and politically visible policies implemented over the past 20 years, which have provided support for farm-gate rice prices and loans to rice farmers (Ricks 2018). Farmers nowadays have opportunities to design their own projects at the local level and get funding for them. However, these projects do not involve any multi-stakeholder initiatives to address the various challenges facing the farms (Buchenrieder et al. 2017; Walker 2012).

Moreover, agricultural policies have been traditionally designed in Thailand in a top-down way, even those geared towards capturing farmers' votes (Ricks and Laiprakobsup 2021). Walker's (2012) detailed assessment of the relationship between farmers and public actors in the Northern Region of Thailand showed that these relations were aimed at organising flows of resources to support farms. A key strategy of rural inhabitants was to make their village "legible to the community development gaze of state agencies and officials" (ibid., p. 186). There was no room for discussing challenges facing the farms and how to best address them. Moreover, Ricks and Laiprakobsup (2021) argued that policy implementation can produce lock-ins, in the sense that they frame actors' expectations about what state intervention should be. They showed that Thai rice farmers' request for support on rice prices was an upshot of the prevailing policies, thereby pushing discussion on more structural issues into the background. Lock-ins also take place on more specific issues. In many irrigation schemes, the Royal Irrigation Department (which is part of the Ministry of Agriculture and Cooperatives) is in charge of irrigation

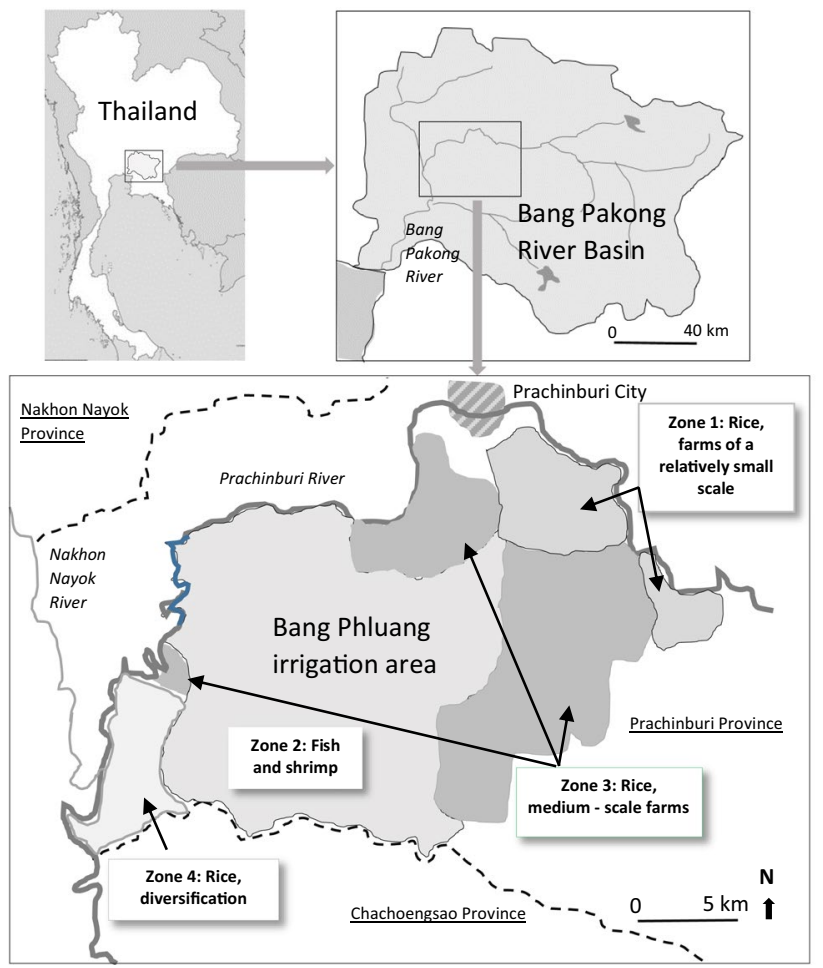

Fig. 1 The Bang Phluang irrigation area

management and has limited communication with farmers located in these schemes. This Department set up water user associations, without discussing the role and functioning of these associations with farmers. In response, the farmers have often lukewarm interest in getting involved in these associations (Ricks 2015).

\section{Method}

\section{Study area}

The Bang Phluang irrigation area (76,000 ha, approximately 8,000 farms) spans 14 subdistricts and is located in low-lying areas on the left bank of the Prachinburi River (Fig. 1). The river becomes the Bang Pakong River after its junction with the Nakhon Nayok River. This area encompasses contrasted farming systems and dynamics. Farms in some subdistricts mostly focus on rice production. Irrigation enables them to grow two rice crops a year. In other subdistricts, farmers jointly raise fish and shrimp in the same ponds. Aquaculture production techniques are complex and farmers have to deal with unstable market prices, but in the study area the average per-ha net profit from fish and shrimp farming was sevenfold higher than that from rice production in 2016 (Aguilhon 2017). 
Fig. 2 Constraints to change towards more profitable farming systems affecting rice farms not having their own tractors (from Faysse et al. 2020)

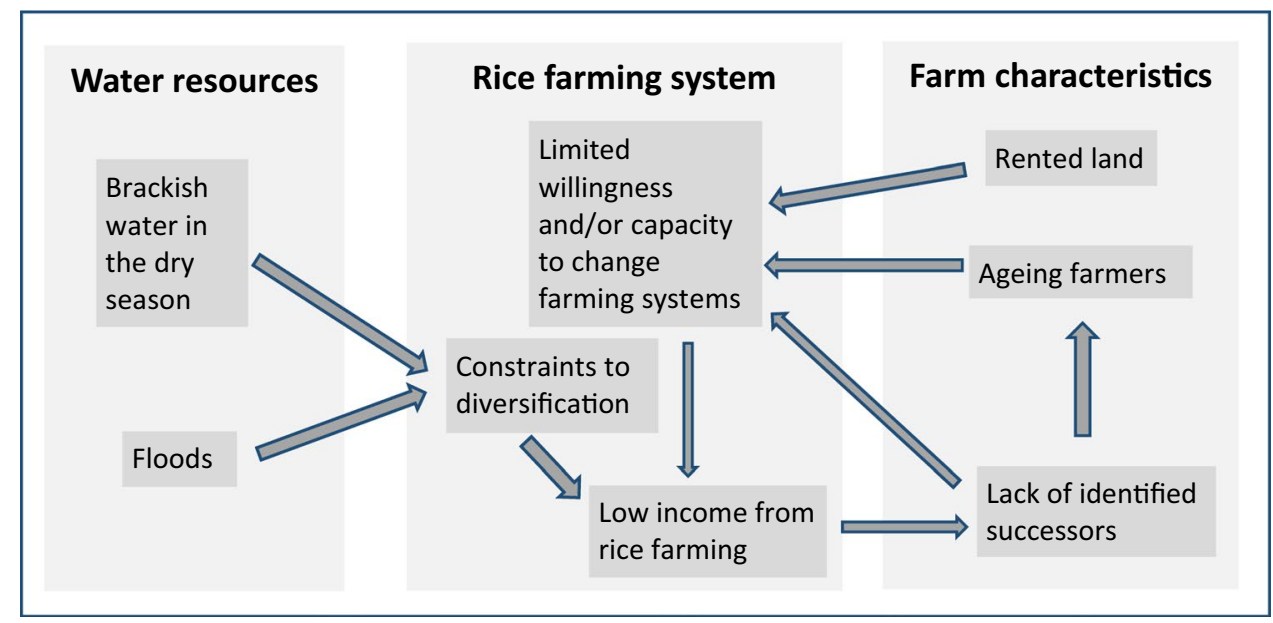

The Royal Irrigation Department manages the main water infrastructures at the catchment level and the water gates connecting the Bang Phluang irrigation area to the Prachinburi River and to neighbouring canals. Farmers are often hampered by a lack of fresh water during the dry season since brackish water coming from the river estuary encroaches the study area (Aguilhon 2017). This brackish water encroachment is especially marked during drought periods. Moreover, as the whole area is low lying (less than $6 \mathrm{~m}$ asl), farms usually have to deal with floods over an average 2-month period during the rainy season.

In the area, there are a few large-scale (approximately $100 \mathrm{ha}$ ) commercial farms devoted to tree farming, yet the vast majority of farms located in the study area are family farms. A survey (Faysse et al. 2020) led to the identification of four types of family farms: i) rice farms without tractors (average $6.0 \mathrm{ha}$ ); ii) rice farms having their own tractors (average $13.4 \mathrm{ha}$ ); iii) fish and shrimp farms (average $4.4 \mathrm{ha}$ ); and iv) farms mixing rice and shrimp rearing and rice farming (average $9.7 \mathrm{ha}$ ).

The assessment that took place before the participatory planning process (Faysse et al. 2020) enabled us to divide the area into four zones based on the main types of farming system present (Fig. 1). Zone 1 is a rice production area mainly involving rice farms that did not have their own tractors. These rice farms were increasingly trapped in a vicious circle, being hampered by low farm profitability, especially since policies to support farm-gate rice prices had been markedly reduced in 2015 . Holders of these farms had difficulties in changing their farming systems (e.g. towards diversification or organic farming), with the main reasons being short-term land rent contracts, floods and lack of sufficient irrigation water during the dry season. Hence, there were few successors to take over the farm, the average age of farm holders was increasing, and ageing farmers showed limited willingness to make profound changes in their farming systems. This in turn impeded farm profitability improvement (Fig. 2). Thus, although these farms could not be considered as small-scale according to various national standards (Tubtim 2019), they generated economic benefits that were too small to ensure their sustainability (Faysse et al. 2020).

In Zone 2, most farms focused on fish and shrimp rearing. Fish and shrimp farms were found to be impeded by production problems and, due to a lack of collective action for marketing, these farmers were not on level ground with intermediaries during price bargaining. Zone 3 is a rice production area mostly involving rice farms having their own tractors. These farmers faced the same problems as those in Zone 1, although to a lesser extent. Their adaptation strategy was generally not to expand but rather to diversify their crop production (Faysse and Phiboon 2019). Finally, Zone 4 is a rice production area mostly involving farms mixing rice farming and fish and shrimp rearing.

Many rice farmers rented land - the majority of farmers of Zone 1 surveyed in Faysse et al. (2020) rented all of the land they farmed. These farmers generally signed 1-2 year rental contracts. Signing short-term rental contracts had not been much of a constraint for farmers producing rice under conventional practices, since farmers had limited needs with respect to making long-term investments in improving their farming fields. However, it had become a major constraint for rice farmers intending to shift to organic practices or to start producing non-rice crops (Faysse and Phiboon 2019). Laws aimed at protecting the rights of tenant farmers are not new in Thailand. A land rent regulation act was enacted in 1974 (Haberkorn 2009), followed by others. The most recent one dates back to 2016. However, the implementation of these laws has been very limited because of a lack of strong political support (Daungbootsri 2017; Haberkorn 2009).

Farms in the Bang Phluang area thus faced many interrelated operational and structural challenges. The operational challenges concerned production, water access, marketing, collective action, and profitability conditions. Structural 
challenges encompassed land rent and youth involvement in farming. Finally, in most families, there was at least one person farming fulltime (Faysse et al. 2020). Despite the difficulties described above, a deagrarianisation process had not yet started. The farm situations in the Bang Phluang area therefore differed from what takes place in other regions of Thailand, such as the Northeast Region, where farms are generally smaller, with less access to irrigation water, and where farming has become a minor component in the livelihoods of many rural families (Rigg 2019). However, because of the above-mentioned challenges, the future of farms in the Bang Phluang area appeared unclear (Faysse et al. 2020).

In the late 2010s, the main agricultural policies in the area were investment in water management (including building of a dam) and support to farmers' groups for collective production and marketing (Faysse et al. 2020). However, the funds and human resources dedicated to the latter policy were limited in the study area, leading to limited impacts. Policies inspired from the sufficiency economy philosophy mainly involved distribution of tree seedlings and fingerlings and had also limited impacts in the study area.

\section{Participatory scenario planning}

The participatory scenario planning process was presented to actors of the Bang Phluang irrigation area as a research initiative and was structured in two main phases: scenario design (Phase 1) and identification of an action plan to achieve the preferred scenario (Phase 2). Several activities in Phase 1 were undertaken with a specific focus on one subdistrict per zone in order to gain full insight into the local farming and water management issues. In Phase 2, each of the four zones was considered as a whole. The process involved farmers (usually the majority of participants in workshops), provincial and subdistrict administration representatives and staff, Ministry of Agriculture and Cooperative staff, as well as Prachinburi River Basin Committee members. The process took place from July 2018 until May 2019.

During Phase 1, we organised scenario-design workshops in each of the four focus subdistricts. In order to prepare preliminary content to support discussion in these workshops, seventeen interviews were conducted in the focus subdistricts with subdistrict administration representatives, heads of villages and farmers. Interviewees were asked about the possible futures that they saw for the farms located in their subdistrict by 2029 . All interviewees chose to express possible futures in terms of a things-getting-worse scenario and an alternative (and better) one. Thus they proposed scenarios based on their desirability and not their likeliness. Based on these interviews, two preliminary scenarios for the future of the farms by 2029 were drawn up in each focus subdistrict. These scenarios and subsequent ones were redacted in the form of short stories.
During the scenario-design workshops, participants (20 on average) discussed past and future drivers of change of farming systems based on the results of the initial assessment. Then the two preliminary scenarios for the focus subdistrict where the workshop was organised were presented. Participants discussed the main features of the scenarios and they provided supplementary content. Participants had the possibility of writing a third scenario if they wanted, but participants in all workshops found it relevant to limit the analysis to two scenarios.

We then drew up a things-getting-worse and an alternative scenario for each zone based on the results of this first series of workshops and on 15 complementary interviews conducted in the 10 other subdistricts in the Bang Phluang irrigation area. Based on agricultural data and these complementary interviews, each of these 10 subdistricts proved to have agricultural characteristics and dynamics broadly similar to one of the four focus subdistricts. We compiled these scenarios. Although the four areas had major differences, the sets of scenarios shared several similarities. This enabled us to write two synthesis scenarios (a things-getting-worse and an alternative scenario) for the whole Bang Phluang irrigation area. We also organised a scenario-design workshop with staff of the provincial administration and representatives from the different departments of the Ministry of Agriculture and Cooperatives at the provincial level.

Phase 2 began with a specific focus on two topics: support to young farmers and better land rent conditions for tenants. During Phase 1, these two topics had emerged as important elements of the designed scenarios, but local actors generally considered that they did not have sufficient information to discuss them. Based on studies carried out on young rural people and young farmers in the study area (Phiboon et al. 2019; Ruiz Salvago et al. 2019), a series of workshops were organised to discuss possible ways to support young people in getting started in farming (Faysse et al. 2019). Similarly, a workshop on land rent practices was also organised, during which participants identified actions to enhance land rent conditions for tenants.

Finally, action plan workshops were organised in each of the four zones. Participants identified and discussed a list of actions to implement the alternative synthesis scenario. Then each participant selected, from within this list, the three actions that he/she considered as being most influential to achieve the preferred scenario. Each participant allocated three points to the action he/she considered as being the most influential, two points for the one he/she ranked second, and one point for the action ranked third. Each participant prioritised actions anonymously. A final workshop was held to present and discuss the results of the whole process. Each individual interview and workshop was recorded. Interviews were transcribed in English. A report of 
each workshop was drawn up in English which summarised the ideas discussed by participants.

\section{Results}

\section{Scenarios}

Table 1 presents the key elements of the eight zone-based scenarios. Each scenario considered differed in terms of water management, farm management, local initiatives and public policies, and youth involvement in farming. Moreover, each of the four sets of two zone-based scenarios gave relatively more importance to one topic: land rent conditions in Zone 1, access to irrigation water in Zone 2, development and strengthening of farmers' collective action in Zone 3, and transition to organic farming and development of rural tourism in Zone 4 . Each of the four things-getting-worse scenarios described a situation where farming was in crisis because most farmers had not been able to successfully undertake actions to address the structural and operational challenges facing their farms, particularly in relation to the topics mentioned above. Either no action took place (land rent conditions in Zone 1), initiated actions were not successful (enhanced water management in Zone 2, farmers' collective action in Zone 3), or only a few farmers managed to successfully adapt (diversification in Zone 2 and organic farming in Zone 4). By contrast, the four alternative scenarios included successful actions to deal with the main structural and operational challenges facing the farms.

The main content of the narrative for the things-gettingworse synthesis scenario is as follows.

In 2029, initiatives to improve water management in the Bang Phluang irrigation area have failed. Most rice farms did not succeed in moving away from conventional farming practices. Some farmers could not deal with the problems they faced so they stopped farming and shifted to other jobs. Many farmers have sold land and some have rented out their land to other farmers from various origins. Only a few farmers managed to secure better access to irrigation water through the installation of individual pumps and the digging of small canals or pipes to bring water from the Prachinburi River to their farms. Farmers' groups were created to improve farming techniques and marketing, especially in the fish and shrimp sector, but these initiatives have failed. Similarly, initiatives to promote rural tourism were of limited success due to insufficient coordination between actors and a limited budget devoted to the development and promotion of tourism activities. Farmers' key focus is now to decrease production costs, and they have not improved the quality of their products nor their capacities to negotiate prices of farm products. Profitability is low and very few young people are interested to become farmers.

The main content of the narrative for the alternative synthesis scenario is as follows.

In 2029, various initiatives have successfully supported the change in farming systems in the Bang Phluang irrigation area. Access to irrigation water during the dry season has improved, for two reasons. First, irrigation infrastructure has been upgraded as a result of an agreement between farmers and the Bang Phluang Irrigation Office, which specifies that many rice fields in the area can be used as flood expansion areas during the rainy season. Second, water users' groups are working better and they are involved in water distribution coordination. Many farms that were previously cropping rice using conventional practices have shifted to produce organic rice or a diverse range of crops. Some farmers made the change alone, while others received government agency support. One element enabling these changes is that lessees have increased security with regard to land rent conditions and thus they can confidently invest in improving the soil characteristics and their farm equipment. Another is that several farmers' organisations are now successfully engaged in technical advice and marketing. Tourism activities (such as visits to cultural places and natural sites, homestays, and visits to organic farms) have developed successfully. Some young people have started farming for three reasons: 1) profitability of farming is satisfying; 2) public policies accompany the installation of young farmers, for instance by supporting cooperation between elder farmers and young people who want to start farming; and 3) young people see that farms can evolve positively in the future.

These two narratives underline the links between drivers of change, actions initiated by farmers and government agencies, and agricultural dynamics. The alternative scenario puts forward how successful cooperation between various actors (e.g. between farmers and the irrigation office, or between elder farmers and young people) increase farmers' ability to make changes in their farming systems.

The content of the zone-based and synthesis thingsgetting-worse scenarios generally prompted consensus. In particular, staff from the Ministry of Agriculture and Cooperatives considered that the things-getting-worse scenario would occur if ongoing public policies were not modified. Debates rather focused on the alternative scenarios. Participants discussed the desirability of some elements of these scenarios. For instance, a few participants rented out land, 
Table 1 Key elements of zone-based scenarios

\begin{tabular}{|c|c|c|}
\hline Zone & Things-getting-worse scenario & Alternative scenario \\
\hline $\begin{array}{l}\text { Zone } 1 \text {. Rice production area, } \\
\text { mainly involving relatively } \\
\text { small-scale farms }\end{array}$ & $\begin{array}{l}\text { A marked decrease in farming } \\
\text { - Few rice farmers have diversified production due to } \\
\text { insecure land access and insufficient water during the } \\
\text { dry season } \\
\text { - Many farmers have sold their farms for construction } \\
\text { purposes } \\
\text { - Rice farmers earn low income because of high farm } \\
\text { production costs and unstable rice prices } \\
\text { - Very few young people take over the farm when they } \\
\text { inherit land }\end{array}$ & $\begin{array}{l}\text { Diversification } \\
\text { - Diversification has expanded because of improved } \\
\text { conditions for land rent and better irrigation } \\
\text { management } \\
\text { - The use of chemical inputs has decreased (par- } \\
\text { ticularly thanks to the development of organic } \\
\text { farming) } \\
\text { - Rural tourism has expanded } \\
\text { - One third of young people living in the area farm } \\
\text { at least part time }\end{array}$ \\
\hline $\begin{array}{l}\text { Zone } 2 \text {. Rice production area, } \\
\text { mostly involving medium-scale } \\
\text { rice farms }\end{array}$ & $\begin{array}{l}\text { A rice sector in crisis } \\
\text { - Few farmers have tried to diversify production due to } \\
\text { a lack of water management improvement } \\
\text { - Rice yields have decreased and pumping costs remain } \\
\text { high so rice profitability has decreased } \\
\text { - Some farmers have stopped farming and some have } \\
\text { rented out land } \\
\text { - Young people are not interested in farming }\end{array}$ & $\begin{array}{l}\text { Increased water control and diversification } \\
\text { - Farmers have access to sufficient irrigation water } \\
\text { - The area is used for flood expansion during the } \\
\text { rainy season } \\
\text { - Rice farmers have improved rice yields and have } \\
\text { decreased pumping costs } \\
\text { - One third of farmers who own land have diversi- } \\
\text { fied their production } \\
\text { - Some young people come back to take over their } \\
\text { parents' farms }\end{array}$ \\
\hline $\begin{array}{l}\text { Zone } 3 . \text { Fish and shrimp as main } \\
\text { production }\end{array}$ & $\begin{array}{l}\text { Individual production and marketing } \\
\text { - Collective action initiatives have failed and water } \\
\text { management has not improved } \\
\text { - Farms have adopted individual strategies to deal with } \\
\text { unstable fish and shrimp prices } \\
\text { - The profitability of fish and shrimp farming has } \\
\text { decreased. Some farmers are indebted, some have } \\
\text { stopped farming, some have rented out their land } \\
\text { - Some young people still get involved in farming }\end{array}$ & $\begin{array}{l}\text { Successful farmers' collective action } \\
\text { - Successful collective actions for improving water } \\
\text { management, improving breeding techniques, } \\
\text { accessing farm inputs at low costs, joint produc- } \\
\text { tion planning, processing plus marketing } \\
\text { - Improvement of farm profitability } \\
\text { - Many young people get involved in farming }\end{array}$ \\
\hline $\begin{array}{l}\text { Zone } 4 \text {. Rice production plus } \\
\text { ongoing diversification and } \\
\text { shrimp breeding }\end{array}$ & $\begin{array}{l}\text { A dormant agriculture } \\
\text { - Rice profitability has decreased because of high farm } \\
\text { production costs and unstable rice prices } \\
\text { - Only a few farmers have adopted organic farming } \\
\text { as farmers sell organic rice at the same price as rice } \\
\text { produced with chemical inputs } \\
\text { - Lack of success of ecotourism projects } \\
\text { - Few young people take over their parents' farms }\end{array}$ & $\begin{array}{l}\text { Organic production and ecotourism projects } \\
\text { - Organic farming and ecotourism projects have } \\
\text { been successful, so farmers have become more } \\
\text { confident in organic crop production and market- } \\
\text { ing } \\
\text { - Improved health of farmers and better environ- } \\
\text { ment } \\
\text { - Decreased farm production costs } \\
\text { - More young people work on farms }\end{array}$ \\
\hline
\end{tabular}

which in the area is usually rented to neighbours and relatives. These participants were initially not in favour of more secure land rent conditions for lessees.

Moreover, while participants initially proposed alternative scenarios as a desired future during personal interviews, they debated the likelihood of these scenarios in the meetings. For instance, participants discussed the development of organic farming. A president of a subdistrict administration mentioned that if "there is no issue of flooding, water pollution, and lack of water during dry season, and if we implement an eco-tourism project, the area will mainly adopt organic rice production under a holistic farm management approach, involving production, certification, processing, and marketing". However, some farmers cropping rice under conventional practices were skeptical about the future growth of organic farming in the area. One farmer mentioned that "opportunities for adopting organic farming are limited because of water issues (especially flooding) and organic farming requires major farm investments". Some farmers were optimistic that young people would be interested in getting involved in farming if farming income were to increase thanks to better access to irrigation water and better marketing. However, other farmers expressed their doubts that young people would be interested in farming, whatever the proposed conditions. One farmer said that even if farming conditions improved "there will be fewer young people working on farms as they prefer working in factories or the cities, and some of them will go back to farm only as a last choice when they have to take over the farm of their parents". These different viewpoints triggered discussions about which actions would be needed to increase the chance of these elements of alternative scenarios occurring. 
Table 2 Main actions to achieve the alternative synthesis scenario

\begin{tabular}{ll}
\hline Dimensions & Actions \\
\hline Water management & Build a weir or ponds to increase water resources during the dry season \\
& Build water gates and extend irrigation canals to improve water distribution \\
& Improve coordination for water management and increase local actors' involvement in decision-making \\
& Set up public subsidies to partially cover irrigation costs \\
& Enhance implementation of the 2016 Land Tenure Act, thanks to capacity-building of tenants and third party \\
involvement during rental contract preparation & Development of active farmers' organisations which help their members improve production, processing and \\
Land rent conditions & marketing \\
Farmers' organisations & $\begin{array}{l}\text { Support the distribution of high-quality agricultural inputs } \\
\text { Farm production and profitability }\end{array}$ \\
& Enhance farmers' access to funding and help them solve debt issues \\
& Promote innovative farming practices such as organic farming \\
Sustained activities to build farmers' capacities & More stable agricultural product prices \\
Marketing & Support for processing and export \\
Rural tourism & Development of organic farm models and local tourist markets so as to promote direct contacts between \\
farmers and consumers & Help young farmers sell in local tourist markets
\end{tabular}

\section{Action plan}

Table 2 shows actions that obtained at least 10 points when summing participants' individual assessments made during the action plan workshops. The proposed actions that focused on farm production, farm profitability, and marketing aimed to enhance farm income in the short term and to enhance farmers' capacity to make changes in their farming systems in the longer term. Participants promoted actions enabling farmers to receive material support, but they also promoted actions enabling farmers to become more active in decision-making at the local level. Farmers and representatives of subdistrict administrations expressed a strong interest in setting up joint management committees, which would enable them to have a voice in decision-making on irrigation issues (such committees are already operating in Thailand, Ricks 2015). But their desire to get involved garnered lukewarm interest from representatives of the Royal Irrigation Department who were used to managing water in a centralised way. Farmers also proposed to be more active in decision-making in agricultural value chains thanks to stronger farmers' organisations.

In the final workshop, the proposed actions to achieve the desired scenario were grouped into three sets that jointly built a pathway of change (Fig. 3). The actions related to the first set were improving land rent conditions for tenants, strengthening farmers' groups, and improving water management. Workshop participants specifically focused on land rent and proposed the involvement of a third party to make sure that the rental contracts meet the legal requirements. They also proposed that contracts should involve a much longer rental period in case tenants would want to invest in the land. Actions of the second set were improving farm production and profitability, diversification and development of organic farming, and improved marketing conditions. Actions of the third set were development of rural tourism and youth involvement in farming. In workshops with young farmers and young inhabitants of the area, participants reviewed various policy options to support youth involvement in farming. They considered that the most promising ways were subsidies to start farming and secure land leases (Faysse et al. 2019). Indeed, youths usually do not have sufficient funds to buy land to start their farms. Signing long-term land rent contracts can help them feel more confident if they start farming on rented land.

The links connecting these sets of actions had been specified in the alternative zone-based and synthesis scenarios. Actions of the first set could support implementation of actions of the second and third sets. For instance, a longer land rent contract duration could help tenant farmers of Zone 1 diversify away from conventional rice farming or launch into organic rice farming. Similarly, actions of the second set can support those of the third set. For instance, improved farm profitability provides higher incentive for young people to get involved, while the development of organic farming can support local organic markets able to attract tourists.

\section{Discussion}

\section{Innovative views on needed farm transformations}

Actions scheduled in the pathway of change addressed the main challenges facing the various types of farms present 
Fig. 3 Pathway of change proposed by participants to achieve more sustainable farms in the Bang Phluang irrigation area

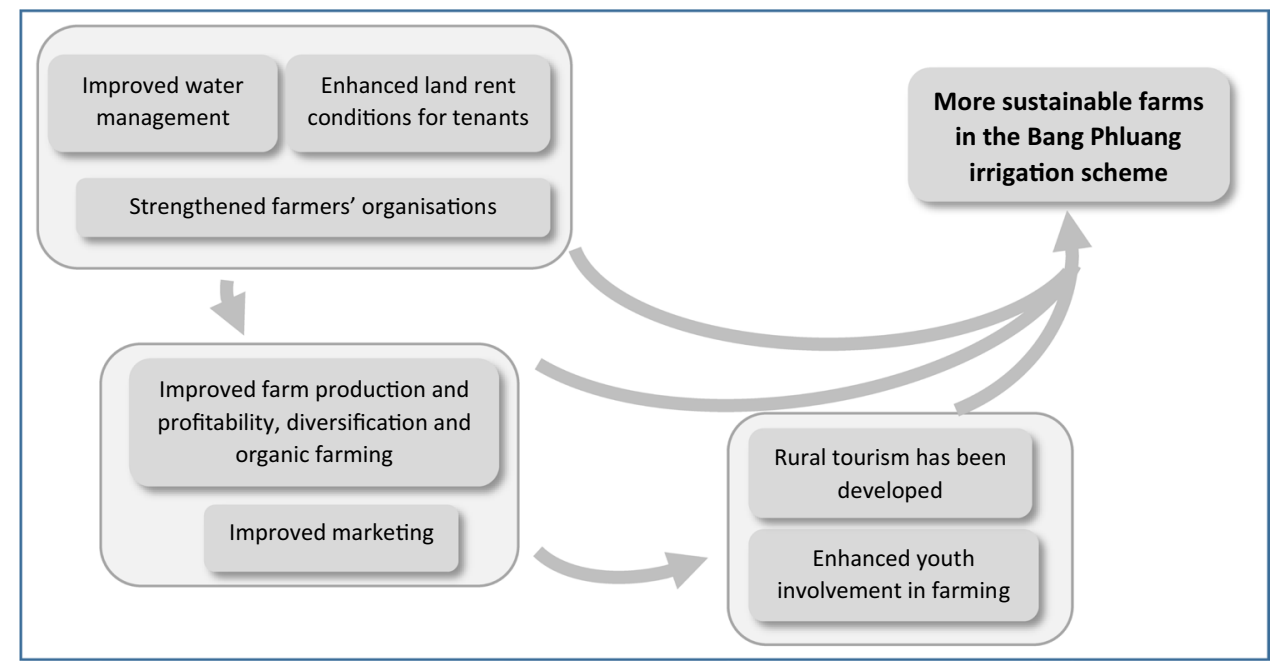

in the Bang Phluang irrigation area. In particular, they tackled the constraints impeding change in relatively small rice farms, as depicted in Fig. 2. Several actions presented in Table 2 are similar to those proposed in Bennett et al. (2016), Butler et al. (2016), and Bourgeois et al. (2017), such as the diversification of agricultural production, the development of farmers' organisations, support of youth engagement in farming, and the development of non-agricultural income generating activities, e.g. tourism. Other actions were more innovative, such as enhanced farmers' participation in decision-making for water management and in agricultural value chains, and development of local markets to enhance direct connections with consumers.

A commonly held view in Thailand and in other Asian NIEs is that rural youth is not interested in farming (Morarji 2014; Rigg et al. 2018). Interviews with young inhabitants of Bang Phluang area undertaken as part of the same research initiative (Ruiz Salvago et al. 2019) showed that many of these young inhabitants were not against farming per se and, in particular, they did not consider that farming was attached to a poor social status. Many interviewees said they would reconsider their lack of willingness to engage in farming in the future if they considered the conditions suitable (as observed by White 2021). Agricultural students in the study area who aimed to become farmers scheduled a long-time trajectory to be able to start in good conditions (Filloux et al. 2019). As LaRue et al. (2021) point out, young people do not necessarily consider farming as a fulltime activity and interviewed students clearly made differences in their plans between farming as a part-time or as a full-time activity.

By contrast, the farm size issue-a highly-discussed structural challenge in Asian NIEs (e.g. Rigg et al. 2016) received limited attention. In the study area, most farms could be considered above the thresholds defining smallholdings at national level (Tubtim 2019), especially given the fact that they had access to irrigation. Local actors considered that even farms of a relatively smaller size in Bang Phluang area could be financially sustainable if they managed to diversify their production through enhanced water management and connection to markets offering remunerative prices.

Participants considered various changes to address structural challenges to farm sustainability (i.e. land rent conditions and the involvement of young farmers), i.e. two issues for which there was in practice no policy applied in the Bang Phluang area. Several actions proposed by participants were scheduled in the 2017-2036 Thai agricultural strategy, such as the support for organic farming development. However, the agricultural strategy presents challenges and scheduled actions as a list of points without showing the connections between them, whereas actors of Bang Phluang had specified the linkages between proposed actions when building a pathway of change.

The scenario planning process took place before the COVID-19 pandemic that meanwhile has been impacting farming conditions in Thailand (Wannaprasert and Choenkwan 2021). Complementary research would be useful to analyse the extent to which the pandemic has affected not only farming conditions in the study area but also how farmers and young people see their futures.

\section{Actors' readiness for change}

Unlike the experiment presented by Butler et al. (2016), participants in the present study focused on transformative changes when selecting the most relevant actions. While participants asked for support regarding farm-gate prices and to cope with debts, they also suggested that state support should be broadened to support the farm transformation process. In doing so, they wanted to break the lock-in prompted by past material support-focused public polices (Ricks and Laiprakobsup 2021). 
This interest in considering transformative change stemmed from the fact that actors in the Bang Phluang irrigation area (including staff of the Ministry of Agriculture and Cooperatives) agreed on the looming crisis in the agricultural sector. They considered that maintaining farming practices and management was not a desirable objective. They also did not want to move "backwards" into an idealised traditional peasant life, as often promoted by the Thai urban elite (Dayley 2011; Tubtim 2019). The participatory process thus fostered collective articulation of the future they did not want, which can be an important step in triggering willingness for change (Bourgeois et al. 2017).

Local actors expressed a collective aspiration for changing farming systems. This aspiration included elements strongly supported by the official discourse. For instance, some actors made reference to the sufficiency economy philosophy when they promoted organic farming and agricultural diversification. This could be labelled as the "doxic" component of participants' collective aspiration (Huijsmans et al. 2021). Participants' aspirations also encompassed other elements that were much more innovative in the Bang Phluang area, e.g. farmers' willingness to get involved in decision making on water management.

However, local actors' willingness to become proactive partners will not be sufficient alone to trigger desired changes. As in other backcasting studies (Hadarits et al. 2017), the proposed pathway of change involved actions to be taken at various scales and by different actors: the national level (e.g. changes in legislation on land tenure, development of new policies to support young farmers), the regional level (e.g. water management) and the local level (e.g. more active farmers' organisations, actual implementation of land tenure policies). Undertaking these actions at various levels in a coordinated way is a challenge, not only because of the weaknesses of subdistrict organisations (Dufhues et al. 2015) and of farmers' organisations at the national level, but also because experience regarding processes involving multiple stakeholders at multiple scales to design and implement policies has been limited in Thailand (Lebel et al. 2011; Marks and Lebel 2016).

\section{Conclusion}

In the study area, local actors (farmers, representatives of local administrative levels, but also staff of local offices of the Ministry of Agriculture and Cooperatives) collectively agreed on possible farm futures. They specified the risks with regard to farm futures in a scenario involving no public policy changes. The vision for the desired future of the farms that actors depicted and the action plan they proposed were not very detailed. Yet participants proved their willingness and capacity to imagine various types of sustainable farms, while proposing ways to address the various challenges facing the farms. They suggested innovative actions to attempt to change trends that were sometimes considered in local discussions as ineluctable, such as the decreased youth engagement in farming.

There is a need to foster multi-stakeholder dialogue on farm futures in Asian NIEs. The present study revealed that, even in a context that did not a priori foster such dialogue, actors of a rural territory could initiate a conversation on challenges facing farms and on possible farm futures, while proposing innovative and ambitious pathways to farm sustainability.

Acknowledgements This work was supported by the Agence Nationale de la Recherche (French National Agency for Research) as part of the DOUBT project.

\section{References}

Aguilhon L (2017) Agricultural dynamics in the Bang Pakong River Basin: Interrelationship between family dynamics, access to the market and water management. Master Thesis, Montpellier University

Ashok K, Nataraja R, Kumar P, Sharma K, Mathur M (2021) Sustainable alternative futures for agriculture in India-the energy, emissions, and resource implications. Env Res Letters 16(6):064001. https://doi.org/10.1088/1748-9326/abf0cd

Bhandari H, Mishra AK (2018) Impact of demographic transformation on future rice farming in Asia. Outlook Agric 47:125-132. https://doi.org/10.1177/0030727018769676

Bennett NJ, Kadfak A, Dearden P (2016) Community-based scenario planning: A process for vulnerability analysis and adaptation planning to social-ecological change in coastal communities. Environ Dev Sust 18:1771-1799. https://doi.org/10.1007/ s10668-015-9707-1

Bourgeois R, Penunia E, Bisht S, Boruk D (2017) Foresight for all: Co-elaborative scenario building and empowerment. Tech Forecasting Social Change 124:178-188. https://doi.org/10.1016/j. techfore.2017.04.018

Buchenrieder G, Dufhues T, Theesfeld I, Nuchanata M (2017) Participatory local governance and cultural practices in Thailand. Cogent Soc Sci 3:1338331. https://doi.org/10.1080/23311886. 2017.1338331

Butler JRA, Bohensky EL, Suadnya W, Yanuartati Y, Handayani $\mathrm{T}$ et al (2016) Scenario planning to leap-frog the Sustainable Development Goals: An adaptation pathways approach. Climate Risk Manag 12:83-99. https://doi.org/10.1016/j.crm.2015.11. 003

Corbridge S, Williams G, Srivastava M, Véron R (eds) (2005) Seeing the State: Governance and Governmentality in India. Cambridge University Press, Cambridge

Daungbootsri A (2017) The land rental market in Thai agriculture and its impact on household welfare [in Thai]. Thailand Research Fund, Bangkok

Dayley R (2011) Thailand's agrarian myth and its proponents. J Asian African Stud 46:342-360. https://doi.org/10.1177/00219 09611400547

Dufhues TI, Theesfeld I, Buchenrieder G (2015) The political economy of decentralization in Thailand: How past and present 
decentralization affects rural actors' participation. Europ J Dev Res 27:793-810. https://doi.org/10.1057/ejdr.2014.68

Egery J (2014) Economic risks in the agricultural sectors of emerging economies: Smallholder perspectives of projects based on Thailand's 'philosophy of sufficiency economy'. Doctoral dissertation, University of Ottawa

Faysse N, Phiboon K (2019) Building capacities for change: Farmers moving away from conventional rice farming in Prachinburi Province, Thailand. J Community Dev Res 12:57-67

Faysse N, Phiboon K, Filloux T (2019) Public policy to support young farmers in Thailand. Outlook Agric 48:292-299. https:// doi.org/10.1177/0030727019880187

Faysse N, Aguilhon L, Phiboon K, Purotaganon M (2020) Mainly farming ...but what's next? The future of irrigated farms in Thailand. J Rural Stud 73:68-76. https://doi.org/10.1016/j.jrurs tud.2019.12.002

Filloux T, Faysse N, Pintobtang P (2019) The long road to becoming a farmer: Thai agricultural students' plans. Outlook on Agriculture 48(4):273-281. https://doi.org/10.1177/0030727019879933

Formoso B (2016) Are Thai peasants still farmers ? The socioeconomic transformation of two villages of Northeastern Thailand. Moussons 28:39-60. https://doi.org/10.4000/moussons.3636

Haberkorn T (2009) An unfinished past: Assassination and the 1974 land rent control act in Northern Thailand. Critical Asian Stud 41:3-35. https://doi.org/10.1080/14672710802631145

Hadarits M, Pittman J, Corkal D, Hill H, Bruce K et al (2017) The interplay between incremental, transitional, and transformational adaptation: A case study of Canadian agriculture. Reg Environ Change 17(5):1515-1525. https://doi.org/10.1007/ s10113-017-1111-y

Hamilton-Hart N (2019) Indonesia's quest for food self-sufficiency: A new agricultural political economy? J Contemporary Asia 49:734-758. https://doi.org/10.1080/00472336.2019.1617890

Huang J (2019) Agricultural growth, transformation and policies in China. In: Zeigler RS (ed) Sustaining global food security: The nexus of science and policy. CSIRO Publishing, Clayton South, Australia, pp 411-442

Huijsmans R, Ambarwati A, Chazali C, Vijayabaskar M (2021) Farming, gender and aspirations across young people's life course: Attempting to keep things open while becoming a farmer. Europ J Dvpt Res 33:71-88. https://doi.org/10.1057/ s41287-020-00302-y

Hutton CW, Hensengerth O, Berchoux T, Tri VP, Tong T et al (2021) Stakeholder expectations of future policy implementation compared to formal policy trajectories: Scenarios for agricultural food systems in the Mekong Delta. Sustainability 13(10):5534. https://doi.org/10.3390/su13105534

Jansuwan P, Zander KK (2021) What to do with the farmland? Coping with ageing in rural Thailand. J Rural Stud 81:37-46. https://doi.org/10.1016/j.jrurstud.2020.12.003

LaRue K, Daum T, Mausch K, Harris D (2021) Who wants to farm? Answers depend on how you ask: A case study on youth aspirations in Kenya. Eur J Dvp Res 33:885-909. https://doi.org/10. 1057/s41287-020-00352-2

Lebel L, Manuta JB, Garden P (2011) Institutional traps and vulnerability to changes in climate and flood regimes in Thailand. Reg Environ Change 11:45-58. https://doi.org/10.1007/ s10113-010-0118-4

Li M, Sicular T (2013) Aging of the labor force and technical efficiency in crop production: Evidence from Liaoning province, China. China Agricultural Economic Rev 5:342-359. https://doi.org/10. 1108/caer-01-2012-0001

Liao L, Long H, Gao X, Ma E (2019) Effects of land use transitions and rural aging on agricultural production in China's farming area: A perspective from changing labor employing quantity in the planting industry. Land Use Policy 88:104-152. https://doi. org/10.1016/j.landusepol.2019.104152

Lorenzen RP (2015) Disintegration, formalisation or reinvention? Contemplating the future of Balinese irrigated rice societies. Asia Pacific J Anthropology 16:176-193. https://doi.org/10.1080/ 14442213.2014.1000953

Lorsuwannarat T (2017) Public participation in budgeting: The new path of budget reform in Thailand. Int J Public Admin 40:385400. https://doi.org/10.1080/01900692.2015.1126730

Losch B, Giordano T, Marzin J, Michaud A (2016) Rural development policy in perspective: Lessons from country case studies and implications for rural development strategies in developing countries. Art-Dev Research Unit Working paper $n^{\circ} 6$.

Marks D, Lebel L (2016) Disaster governance and the scalar politics of incomplete decentralization: Fragmented and contested responses to the 2011 floods in Central Thailand. Habitat Int 52:57-66. https://doi.org/10.1016/j.habitatint.2015.08.024

Moya P, Kajisa K, Barker R, Mohanty S, Gascon F, et al. (2015) Changes in rice farming in the Philippines: Insights from five decades of a household-level survey. IRRI, Los Banos

Morarji K (2014) Subjects of development: teachers, parents and youth negotiating education in rural North India. Europ J Dvpt Res 26(2):175-189. https://doi.org/10.1057/ejdr.2013.55

Nathan SSB, Rosli MM (2016) Distributional effects of non-farm incomes in a Malaysian rice bowl. Int J Soc Economics 43:205220. https://doi.org/10.1108/ijse-09-2013-0200

Ngah I, Saad H, Kamarudin KH (2013) Socio economic transformation of rice cultivation area in Malaysia: A case of two villages in Sabak Bernam. Rural Research and Planning Group Fourth International Meeting \& Workshop. Institut Teknologi Bandung, Indonesia, 9-10 September.

Nilsen J (2014) Remittances and Development: The impact of remittances on livelihood security. Evidence from Ko Kaeo sub-district, Thailand. Master Thesis, University of Agder

Office of Agricultural Economics (2017) 2017-2036 Agricuture and cooperative strategy. Accessed in June 2018 from: http://www. oae.go.th/view/1

Ozturk I (2009) A case study on changing livelihood strategies of the community of Ban Non Sao-e village, Nakhon Ratchasima Province, Thailand. Europ J Dev Res 21:250-263. https://doi.org/10. 1057/ejdr.2008.21

Phiboon K, Cochetel C, Faysse N (2019) Support programmes and the diversity of young farmers in Thailand: A good match? Outlook Agric 8:300-308. https://doi.org/10.1177/0030727019880559

Podhisita C (2017) Household dynamics, the capitalist economy, and agricultural change in rural Thailand. Southeast Asian Stud 6:247-273

Purushothaman S, Patil S, Francis I, König HJ, Reidsma P, Hegde S (2013) Participatory impact assessment of agricultural practices using the land use functions framework: case study from India. Int J Biodiversity Sc, Ecosystem Services \& Mgt 9(1):2-12. https:// doi.org/10.1080/21513732.2012.721005

Ricks JI (2018) Public choice, institutional change, and rural subsidies: Politics and the price of rice in Thailand. J Contemporary Asia 48:395-418. https://doi.org/10.1080/00472336.2017.1419275

Ricks JI (2015) Pockets of participation: Bureaucratic incentives and participatory irrigation management in Thailand. Water Alternatives 8(2).

Ricks JI, Laiprakobsup T (2021) Becoming citizens: Policy feedback and the transformation of the Thai rice farmer. J Rural Stud 81:139-147. https://doi.org/10.1016/j.jrurstud.2020.10.003

Rigg J, Phongsiri M, Promphakping B, Salamanca A, Sripun M (2020) Who will tend the farm? Interrogating the ageing Asian farmer. J Peasant Stud 47:306-325. https://doi.org/10.1080/03066150. 2019.1572605 
Rigg J, Salamanca A, Phongsiri M, Sripun M (2018) More farmers, less farming? Understanding the truncated agrarian transition in Thailand. World Dev 107:327-337. https://doi.org/10.1016/j. worlddev.2018.03.008

Rigg J, Salamanca A, Thompson EC (2016) The puzzle of East and Southeast Asia's persistent smallholder. J Rural Stud 43:118-133. https://doi.org/10.1016/j.jrurstud.2015.11.003

Rigg J, Salamanca A, Parnwell M (2012) Joining the dots of agrarian change in Asia: A 25 year view from Thailand. World Dev 40:1469-1481. https://doi.org/10.1016/j.worlddev.2012.03.001

Rigg J (2019) More than rural: Textures of Thailand's agrarian transformation. Hawaii University Press, Honolulu

Ruiz Salvago M, Phiboon K, Faysse N, Nguyen TPL (2019) Young people's willingness to farm under present and improved conditions in Thailand. Outlook Agric 48:282-291. https://doi.org/10. 1177/0030727019880189

Sawaengsak W, Prasara-A J, Gheewala SH (2021) Assessing the socio-economic sustainability of sugarcane harvesting in Thailand. Sugar Tech 23(2):263-277. https://doi.org/10.1007/ s12355-020-00888-x

Sartas M, Schut M, Proietti C, Thiele G, Leeuwis C (2020) Scaling readiness: Science and practice of an approach to enhance impact of research for development. Agr Sys 183:102874. https://doi.org/ 10.1016/j.agsy.2020.102874

Susilowati SH (2014) Attracting the young generation to engage in agriculture. In: Proceedings of the international seminar on enhanced entry of young generation into farming Food and Fertilizer Technology Center, Jeonju (South Korea), 21-23 October 2014, pp 105-124

Tubtim T (2019) Thailand: The Political Economy of Post-Peasant Agriculture. In: Thompson E, Gillen J, Rigg J (eds) Asian smallholders in comparative perspective. Amsterdam University Press, Amsterdam, pp 271-306
Walker A (2012) Thailand's Political Peasants: Power in the Modern Rural Economy. University of Wisconsin Press, Madison, US

Walker A (2015) From legibility to eligibility: Politics, subsidy and productivity in rural Asia. Trans-Reg Natl Stud Southeast Asia 3:45-71. https://doi.org/10.1017/trn.2014.17

Wannaprasert P, Choenkwan S (2021) Impacts of the COVID-19 pandemic on ginger production: Supply chains, labor, and food security in Northeast Thailand. Forest Soc 5(1):120-135. https://doi. org/10.24259/fs.v5i1.11897

White B (2021) Human capital theory and the defectology of aspirations in policy research on rural youth. Europ J Dvpt Res 33(1):54-70. https://doi.org/10.1057/s41287-020-00300-0

Xiaoyun L, Xiaoqian L (2010) Stalemate of participation: Participatory village development planning for poverty alleviation in China. In: Long N, Jingzhong Y, Yihuan W (eds) Rural transformations and development - China in context: The everyday lives of policies and people. Edward Elgar Editions, Cheltenham, pp 312-326

Xue Y, Mao K, Weeks N, Xiao J (2020) Rural reform in contemporary China: Development, efficiency, and fairness. J Contemporary China. https://doi.org/10.2139/ssrn.3649179

Zhao J, Wang Z (2020) Future trends of water resources and influences on agriculture in China. PLoS One 15(4):e0231671. https://doi. org/10.1371/journal.pone.0231671

Publisher's note Springer Nature remains neutral with regard to jurisdictional claims in published maps and institutional affiliations. 